\title{
Social environment and reproduction in female pouched mice, Saccostomus campestris
}

\author{
Lilian M. Westlin-van Aarde \\ Mammal Research Institute, University of Pretoria, Pretoria 0002, South Africa
}

\begin{abstract}
Summary. Pouched mice were kept under controlled conditions of illumination (10D: $14 \mathrm{~L})$ and temperature $\left(22 \pm 2^{\circ} \mathrm{C}\right)$. Age at vaginal opening, first oestrus and first conception did not differ significantly between juvenile females raised singly, in singlesex groups of 5 , or with an adult male. After the introduction of a male, sterile cycles and/or matings before first conception were experienced by all females whether they were raised singly or in single-sex groups. Of 10 females raised with a male, 4 conceived at their first mating. Onset of puberty in juvenile females raised with an adult female was delayed, while in juvenile females raised with their families (mother, father and litter mates) only vaginal opening was delayed. However, when raised in family groups without the father, vaginal opening as well as first oestrus were delayed.

Grouping of females after weaning, with or without a male, did not change the oestrous cycle pattern. Females in these groups cycled independently of each other and the females grouped with a male also mated and conceived independently of each other.

Pregnancy was blocked in 7 of 8 females when the stud male was removed and a strange male was introduced. In females exposed to a succession of males, pregnancy was blocked up to 4 times.
\end{abstract}

Keywords: pouched mice; social environment; puberty; cyclicity; pregnancy block

\section{Introduction}

The pouched mouse, (Saccostomus campestris), is an African rodent ( $\sim 100 \mathrm{~g})$ of the subfamily Cricetomyinae. These mice are nocturnal, terrestrial and burrow dwelling (Smithers, 1983), and they breed easily under laboratory conditions (Westlin-van Aarde, 1988) although severe female aggression towards males has been observed under certain conditions in the laboratory (Pitchford \& Visser, 1970; Earl, 1978, 1980; Westlin-van Aarde, 1988). Based on incidental observations under laboratory conditions, Earl (1980) suggested that the pouched mouse is a solitary species. Smithers (1971) reports that pouched mice occur singly, in pairs or family groups, depending on the habitat. Although they occasionally may be found in aggregations in the field, in the burrows only single animals are found except during the breeding season when a lactating mother may be found with her young (G. T. H. Ellison, personal communication).

Studies on the influence of social environment on female reproduction in mammals have been conducted on a number of species (see Vandenbergh, 1983a; Marchlewska-Koj, 1984, for reviews). Puberty in females is accelerated by the presence of an adult intact male in many rodents, farm animals and in a primate (see Vandenbergh, 1983a). It may also be suppressed by the presence of other females, or when the juvenile females are raised with their families (Vandenbergh, 1983a).

The oestrous cycle pattern may be influenced by several factors, such as grouping versus solitariness and presence or absence of an adult intact male (see McClintock, 1983, for references). 
Exposure to a strange male terminates pregnancy in several species of newly mated rodents (see Marchlewska-Koj, 1984, for references).

The present study describes the influence of different social environments on reproduction in captive female pouched mice, in terms of puberty, oestrous cycle pattern and early pregnancy.

\section{Materials and Methods}

Animals. Pouched mice were bred at the Mammal Research Institute, University of Pretoria, South Africa, and

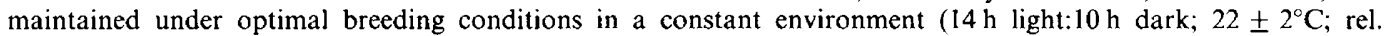
humidity $=52 \%$ ), as described by Westlin-van Aarde (1988). From weaning, at 25 days of age (Westlin-van Aarde, 1988), females were housed as follows.

Puberty studies. Juvenile females were kept (a) singly $(\mathrm{N}=10)$, (b) in groups of 5 (2 sibling-groups) $(\mathrm{N}=20)$ or (c) paired with an adult male known to be fertile $(\mathrm{N}=10)$. Ages at vaginal opening were noted, and from then onwards vaginal smears were taken twice daily. On the day of first pro-oestrus, the single and grouped females were each paired with an adult male known to be fertile. Ages at first oestrus, first conception and the number of sterile cycles and/or sterile matings before first conception were recorded for all females.

Juvenile females were paired with an adult non-related cycling female (Group d). Of 15 tested adult females, 11 were extremely aggressive towards the juvenile females, attacking them, and the experiments were interrupted. The other 4 adult females accepted the presence of a juvenile female. Vaginal opening and first oestrus were recorded and on the day of first pro-oestrus an adult male of proven fertility was introduced to the cage.

Juvenile females were kept with their families, i.e. litter mates (both sexes), father and mother $(N=8)$ (Group e) or litter mates (both sexes) and the mother $(=$ families in which the adult male was not accepted after parturition by the adult female: Westlin-van Aarde, 1988) $(\mathrm{N}=8)$ (Group f). Ages at vaginal opening in the juvenile females were noted, and from then onwards vaginal smears were taken twice daily. Ages at first oestrus, first conception (only in the groups in which the father was present) and the numbers of sterile cycles and/or sterile matings before first conception were recorded. Vaginal smears were taken twice daily in the adult female from the day when the young were 25 days old. The sex ratio at birth in pouched mice does not differ from 1:1 (Westlin-van Aarde, 1988).

Cyclicity studies. Females were kept in single-sex groups of 5 from weaning to the age of 60 days when experiments started. Cyclicity was then studied in females kept in groups of $5(\mathrm{~N}=20$, no. of cycles $=112)$ or in groups of 4 plus an adult male of proven fertility $(\mathrm{N}=16$, no. of cycles $=32$ ). Vaginal smears were taken twice daily to establish the pattern of the oestrous cycle and possible matings in the females kept in groups with a male. Pouched mice have a 4-day cycle as judged by vaginal smears (Westlin-van Aarde, 1988). The results were compared with results from earlier studies on cyclicity in pouched mice (young or adult females, kept singly or with an adult male, but separated from him by wire mesh; Westlin-van Aarde, 1988).

In another experiment females were kept singly from weaning and then in groups of 5 from Day 60 of age but overt aggression and fighting between the grouped females did not allow the completion of this experiment.

Pregnancy block studies. From weaning until the age of 60 days, females were kept in single-sex groups of 5 . From Day 60 each female $(N=8)$ was housed with a male. Vaginal smears were taken twice daily throughout the study and a copulatory plug in the vagina and/or spermatozoa in the vaginal smear were taken as evidence that mating had occurred. The male was removed on the day of confirmed mating and on the next day (=day of metoestrus) a nonrelated, unfamiliar male was placed with the female. After 4 days the females were killed (overdose of anaesthetic ether) and dissected. The ovaries were examined for presence of corpora lutea and the uterine horns for swellings as indication of implantation (would be Day 6 of pregnancy).

Another group of females $(\mathrm{N}=8)$ was treated similarly, but each female was exposed to a succession of males until she became pregnant or at most 6 males. The females were killed and dissected 5 days after the mating after which cyclicity ceased $(\mathrm{N}=7$ ), or 3 days after exposure to the last male (a female in which pregnancies were blocked by all males introduced to the cage).

Statistics. For comparing age at vaginal opening, first oestrus and first conception, A t test was performed between each of the groups (see Table 1). A one-way analysis of variance was used for comparing the number of sterile cycles and/or matings before first conception in pubertal females and a $\chi^{2}$ test was used for comparing cycle lengths in females housed under different conditions.

\section{Results}

\section{Puberty studies}

Quantitative data (including statistics) on sexual development in juvenile females housed from weaning in different social environments (Groups a, b, c, d, e and f) are shown in Table 1. 
Table 1. Sexual development in juvenile female pouched mice housed from weaning in different social environments

\begin{tabular}{|c|c|c|c|c|c|c|c|c|c|c|c|}
\hline \multirow[b]{3}{*}{ Group } & \multirow[b]{3}{*}{ Housing } & \multirow[b]{3}{*}{ No. } & \multicolumn{6}{|c|}{ Age (days) at: } & & & \\
\hline & & & \multicolumn{2}{|c|}{$\begin{array}{l}\text { Vaginal } \\
\text { opening* }\end{array}$} & \multicolumn{2}{|c|}{$\begin{array}{c}\text { First } \\
\text { oestrus† }\end{array}$} & \multicolumn{2}{|c|}{$\begin{array}{c}\text { First } \\
\text { conception }\end{array}$} & \multicolumn{3}{|c|}{$\begin{array}{c}\text { No. of sterile } \\
\text { cycles and/or matings§ }\end{array}$} \\
\hline & & & Mean & s.d. & Mean & s.d. & Mean & s.d. & Mean & s.d. & Range \\
\hline a & Singly & 10 & $36 \cdot 0$ & $5 \cdot 08$ & $44 \cdot 2$ & $5 \cdot 88$ & $59 \cdot 0$ & $18 \cdot 58$ & $3 \cdot 4$ & $3 \cdot 31$ & $1-10$ \\
\hline $\begin{array}{l}\mathrm{a} \\
\mathrm{b}\end{array}$ & $\begin{array}{l}\text { Single-sex } \\
\text { groups of } 5\end{array}$ & 20 & $34 \cdot 5$ & 1.96 & $44 \cdot 7$ & 3.96 & $56 \cdot 0$ & 5.02 & $2 \cdot 8$ & 1.41 & $1-6$ \\
\hline \multirow[t]{3}{*}{$\mathrm{c}$} & Paired with & & & & & & & & & & \\
\hline & & 10 & $37 \cdot 1$ & 3.93 & $45 \cdot 2$ & $4 \cdot 02$ & $55 \cdot 1$ & $15 \cdot 04$ & $2 \cdot 3$ & $3 \cdot 62$ & $0-10$ \\
\hline & $\begin{array}{l}\text { adult } q \\
\text { Family group }\end{array}$ & 4 & $45 \cdot 3$ & $3 \cdot 77$ & $55 \cdot 3$ & $7 \cdot 85$ & $64 \cdot 3$ & $8 \cdot 54$ & $2 \cdot 5$ & 1.29 & $1-4$ \\
\hline \multirow{2}{*}{$\mathrm{e}$} & ( $d^{*}+4+$ young) & 8 & $41 \cdot 9$ & 3.98 & $45 \cdot 0$ & 3.02 & $55 \cdot 1$ & $5 \cdot 36$ & $2 \cdot 4$ & 0.92 & $1-4$ \\
\hline & ( $q+$ young) & 8 & $43 \cdot 4$ & $2 \cdot 20$ & $5 l \cdot 4$ & 3.74 & - & - & - & 一 & $\ldots$ \\
\hline
\end{tabular}

*The following groups differed from each other: $t_{\mathrm{a}-\mathrm{d}}=3.069, \mathrm{df}=12, P<0.01 ; t_{\mathrm{b}-\mathrm{d}}=8.001, \mathrm{df}=22, P<0.001$; $t_{\mathrm{c}-\mathrm{d}}=3.304, \mathrm{df}=12, P<0.01 ; t_{\mathrm{a}-\mathrm{e}}=2.528, \mathrm{df}=16, P<0.03 ; t_{\mathrm{b}-\mathrm{e}}=5.009, \mathrm{df}=8, P<0.001 ; t_{\mathrm{c}-\mathrm{e}}=2.405$, $\mathrm{df}=16, P<0.03 ; t_{\mathrm{a}-\mathrm{f}}=4.135, \mathrm{df}=13, P<0.01 ; t_{\mathrm{b}-\mathrm{f}}=10.071, \mathrm{df}=26, P<0.001 ; t_{\mathrm{c}-\mathrm{f}}=3.811, \mathrm{df}=16$, $P<0.0$ l.

$†$ The following groups differed from each other: $t_{\mathrm{a}-\mathrm{d}}=2.671, \mathrm{df}=12, P<0.025 ; t_{\mathrm{a}-\mathrm{f}}=2.855, \mathrm{df}=16, P<0.02$; $t_{\mathrm{b}-\mathrm{d}}=3.835, \mathrm{df}=22, P<0.001 ; t_{\mathrm{b}-\mathrm{f}}=3.982, \mathrm{df}=26, P<0.001 ; t_{\mathrm{c}-\mathrm{d}}=2.928, \mathrm{df}=12, P<0.015 ; t_{\mathrm{c}-\mathrm{f}}=$ $3 \cdot 183, \mathrm{df}=16, P<0.01 ; t_{\mathrm{e}-\mathrm{d}}=2.975, \mathrm{df}=10, P<0.02, t_{\mathrm{e}-\mathrm{f}}=3.545, \mathrm{df}=14, P<0.01$.

$¥$ Group d differed only from Group b: $t=2 \cdot 521, \mathrm{df}=22, P<0 \cdot 02$.

$\S$ No difference between the groups: $\mathrm{F}=0.332, \mathrm{df}=3$ and $40 ; P>0.05$.

Age at vaginal opening in females kept (a) singly, (b) in single-sex groups of 5 or (c) paired with an adult male did not differ significantly between the groups (see Table 1). Mean age at first oestrus or first conception also did not differ significantly between the groups. The number of sterile cycles and/or sterile matings experienced before first conception varied within the groups, but did not differ significantly between the groups (see Table 1). Of the 10 juvenile females kept with an adult male, 4 conceived at their first mating.

When females were raised with their families, with (Group e) or without (Group $f$ ) the father present, opening of the vagina was delayed (5-7 and 6-9 days delay, respectively) (see Table 1). First oestrus, however, was only delayed when the family females were raised without their father (4-7 days delay). First conception was not delayed in females raised in complete family groups (Group e) and the number of sterile cycles and/or sterile matings before conception was similar to that of the other groups. The mothers in the complete family groups mated and conceived 6-7 days (mean 2 days, s.d. $=4 \cdot 2 ; \mathrm{N}=8$ ) around ( 4 females before, 4 females after) the time of vaginal opening in the daughters.

In the experimental groups in which juvenile females were placed in a cage with an adult female (Group d), most adult females did not accept the presence of a juvenile female, and attacked them frequently to such an extent that the experiments were interrupted. Four females, however, did accept the presence of a juvenile female. In this group, opening of the vagina and first oestrus occurred significantly later (2-11 and 4-11 days later respectively) than in juvenile females housed singly (Group a), in single-sex groups (Group b) or with an adult intact male (Group c), but at an age similar to that of females raised with their family without a father (see Table 1). The females experienced 1-4 sterile cycles and/or sterile matings before the first conception, which occurred at a significantly later age than in juvenile females kept in single-sex groups, but not later than in juvenile females kept singly or with an adult intact male (Table 1). 


\section{Cyclicity studies}

Different social environments did not influence the pattern of the oestrous cycle. The mean length of the oestrous cycle varied from 3.9 days (s.d. $=0.56 ; \mathrm{N}=5, n=29$ ) (young females housed with an adult male but separated from him by wire mesh; Westlin-van Aarde, 1988) to 4.2 days (s.d. $=0 \cdot 37 ; \mathrm{N}=16, n=32$ ) (females grouped 4 per cage plus an adult male; present study) (all groups tested: $\chi^{2}=4.35, \mathrm{df}=5 ; P<0.5$ ).

Females kept in groups of 5 since weaning cycled regularly, the mean length of the cycle being $4 \cdot 0$ days (s.d. $=0 \cdot 13 ; \mathrm{N}=20, n=112$ ). The females cycled independently of each other.

Females housed singly since weaning and which were put in groups of 5 at an age of 60 days started fighting immediately after being grouped. All experimental work on these groups therefore had to be interrupted and no data on their oestrous cycles could be obtained.

Females housed in groups of 4 with an adult male being introduced when they were 60 days old cycled regularly, most of them independently of each other. Only in one group did females temporarily show non-cyclic vaginal smears (leucocytes and mucus), which changed to cyclic synchronized smears when a male was introduced. After 8 days, the females were in different phases of the cycle again. All females $(N=16)$ grouped with a male mated with him independently of each other and 6 of them became pregnant. The mean number of sterile cycles and/or sterile matings before conceiving was $1 \cdot 1$ (range 0-3) (pregnancies were confirmed during autopsies at the end of the experiment). In 3 of the 10 females that did not conceive during the experiment the vaginal smears changed from cyclic to that of a pregnant female (see Westlin-van Aarde, 1988). At dissection, these females had large red corpora lutea but no apparent mammary development. One of the females had swollen well vascularized uterine horns.

The 7 non-pregnant females with regular 4-day cycles throughout the experiment all had small pale corpora lutea.

\section{Pregnancy block studies}

Pregnancy was blocked in all but one female $(\mathrm{N}=8)$ in the experimental group where one strange male was introduced. In females given a succession of males, pregnancies were blocked in all but one female $(\mathrm{N}=8)$. The mean number of pregnancies blocked per female was $3 \cdot 3$ (s.d. $=$ $0 \cdot 76$, range $2-4 ; n=23$ ). The oestrous cycle length from the time when the first strange male was introduced did not change (mean $=4 \cdot 0$, s.d. $=0 \cdot 56 ; n=23$ ). As judged by the vaginal smears, the variation in length that occurred (3-5 days) was not due to prolonged oestrus (Westlin-van Aarde, 1988), but rather caused by shortening or lengthening any stage of the cycle. Normally, spermatozoa are found in the vaginal smears only in the morning of oestrus (Westlin-van Aarde, 1988), but in this experimental group spermatozoa were on two occasions found on other days.

\section{Discussion}

The onset of puberty is known to be accelerated by stimuli from an adult male in several species of rodents, farm animals and in a primate (see Vandenbergh, 1983a, for references). In the present study, however, puberty was not accelerated by an adult male. Moreover, puberty in female pouched mice was not suppressed by the presence of other females of the same age. When juveniles were kept with non-pregnant, non-lactating and unrelated adult females, however, vaginal opening and first oestrus were delayed, which disagrees with the situation in gerbils (Payman \& Swanson, 1980) and house mice (Drickamer \& Hoover, 1979). In spite of the delayed vaginal opening and first oestrus, the age at first conception in these females was not delayed; the statistically significant difference between the group above and juvenile females kept in single-sex groups (see Table 1) is of doubtful biological significance and may have been produced as a result of the unavoidably small sample size. Since the inhibition only lasted until the male was introduced into the cage, the effect of 
the adult female on the juvenile female may have been reversed by the presence of a male (see Group d, Table 1). In contrast to the work on gerbils by Payman \& Swanson (1980), vaginal opening was delayed in females raised with their families (with or without their father), although the mother was not lactating, or recently conceived ( 4 of 8 ). One should, however, consider that pouched mice experience a lactational anoestrus and will not become pregnant before weaning. This initial inhibitory effect of the mother seemed to be counteracted by the presence of the father (compare with Group d above; see Table 1).

Social and physical events can change the endogenous rhythm of the ovarian cycle. By convention (see Vandenbergh, 1983b), the 'normal' cycle length is considered to be that of a female living by herself in a laboratory, even though this is a highly artificial condition. In several species (e.g. guinea-pigs: Cavia porcellus; Wistar rats; Sprague-Dawley rats; cows) the ovarian cycle length is shortened when a female lives in an all-female group (see McClintock, 1983, for references), while in mice, deer mice (Lombardo \& Terman, 1980), Indian field mice, Mus booduga (Dominic \& Pandey, 1979), and wild hopping mice, Notomys alexis (Breed, 1976), gouping of females increases cycle length (the Lee-Boot effect: Andervont, 1944; van der Lee \& Boot, 1955, 1956). The maximum suppressive effect in mice is obtained in groups with $4-6$ members (Champlin, 1971). The oestrous cycle length in female pouched mice housed in single-sex groups ( 5 per cage) since weaning was, however, neither shortened nor lengthened compared to the cycle length of females kept singly (Westlin-van Aarde, 1988).

In several rodent species, olfactory signals from a male can generate oestrous synchrony if the females' oestrous cycles have been delayed or suppressed by living in all-female groups (see McClintock, 1983, for references). This does not seem to be a general feature of pouched mice; in the group in which it did occur, its short duration and the time that elapsed before it started suggest that the synchronization was incidental.

The presence of a male shortens the oestrous cycle in rats (Aron, 1979; Sánchez-Criado, 1982) and deer mice (Bronson \& Dezell, 1968). The lack of such effect in the present study indicates that presence of a male may not be of vital importance for the regulation of oestrous cycle length in pouched mice.

Large red corpora lutea and vaginal smears typical of pregnancy in the grouped, mated, nonpregnant females indicate pseudopregnancy (see Weir \& Rowlands, 1973) rather than a prolonged luteal phase as a result of grouping (see McClintock, 1983, for references).

Pregnancy block has been reported in a number of rodents such as house mice, deer mice, Mongolian gerbils, several species of microtids (see Marchlewska-Koj, 1984, for references), and it was also demonstrated in pouched mice in the present study. The successive blocking of pregnancies (confirmed by vaginal smear patterns) by a succession of males agreed with that described for meadow voles (Clulow \& Mallory, 1974).

The introduction of the first male at the start of the experiment, and an average interval of 4 days ( $=$ a cycle) at which the females were exposed to a succession of males, suggest that a female pouched mouse needs a comparatively short time to distinguish between males (see Bruce, 1961). This agrees with earlier findings in mice, for which Bloch (1974) demonstrated that the female terminates pregnancy not because she recognizes the male that performed coitus (Lott \& Hopwood, 1972), but because she is accustomed to the male's odour after having been with him for a long time.

The extreme interindividual aggression in certain circumstances in the present study, and the lack of response by the females to most social environments tested, support the suggestion by Earl (1980), that the pouched mouse is a solitary species.

This study was financially supported by the University of Pretoria and the Foundation for Research Development. I thank Dr H. Dott for support with computer work. 


\section{References}

Andervont, H.B. (1944) Influence of environment on mammary cancer in mice. J. natn. Cancer Inst. 4, 579-581.

Aron, C. (1979) Mechanisms of control of the reproductive function by olfactory stimuli in female mammals. Physiol. Rev. 59, 229-282.

Bloch, S. (1974) Observations on the ability of the stud male to block pregnancy in the mouse. J. Reprod. Fert. 38, 469-471.

Breed, W.G. (1976) Effect of environment on ovarian activity of wild hopping mice (Notomys alexis). $J$. Reprod. Fert. 47, 395-397.

Bronson, F.H. \& Dezell, H.E. (1968) Studies on the estrus-inducing (pheromonal) action of male deer mouse urine. Gen. comp. Endocrinol. 10, 339-343.

Bruce, H.M. (1961) Time relations in the pregnancyblock induced in mice by strange males. $J$. Reprod. Fert. 2, 138-142.

Champlin, A.K. (1971) Suppression of oestrus in grouped mice: the effects of various densities and the possible nature of the stimulus. J. Reprod. Fert. 27, $233-241$.

Clulow, F.V. \& Mallory F.F. (1974) Ovaries of meadow voles, Microtus pennsylvanicus, after copulation with a series of males. Can. J. Zool. 52, 265-267.

Dominic, C.J. \& Pandey, S.D. (1979) Suppression of oestrus-inducing pheromone production in the Indian field mouse, Mus booduga Gray, by treatment with antiandrogen. Endokrinologie 75, 1-5.

Drickamer, L.C. \& Hoover, J.E. (1979) Effects of urine from pregnant and lactating female house mice on sexual maturation of juvenile females. Dev. Psychobiol. 12, 545-551.

Earl, S.M.J.A. (1980) Development of behaviour in the pouched mouse Saccostomus campestris. M.Sc. thesis, Faculty of Science, University of Pretoria, South Africa.

Earl, Z. (1978) Postnatal development of Saccostomus campestris. African Small Mammal Newsletter 2, $10-12$.

Lombardo, D.L. \& Terman, C.R. (1980) The influence of the social environment on sexual maturation of female deer mice (Peromyscus maniculatus bairdi). Res. Popul. Ecol. (Kyoto) 22, 93-100.

Lott, D.F. \& Hopwood, J.H. (1972) Olfactory pregnancyblock in mice (Mus musculus): an unusual response acquisition paradigm. Anim. Behav. 20, 263-267.
Marchlewska-Koj, A. (1984) Pheromones and mammalian reproduction. Oxford Rev. Reprod. Biol. 6, 266-302.

McClintock, M.K. (1983) Pheromonal regulation of the ovarian cycle: enhancement, suppression and synchrony. In Pheromones and Reproduction in Mammals, pp. 113-149. Ed. J. G. Vandenbergh. Academic Press, New York.

Payman, B.C. \& Swanson, H.H. (1980) Social influence on sexual maturation and breeding in the female Mongolian gerbil Meriones unguiculatus). Anim. Behav. 28, 528-535.

Pitchford, R.J. \& Visser, P.S. (1970) Saccostomus campestris Peters, 1846 as a laboratory animal. J. $S$. Afr. vet. med. Ass. 41, 173-174.

Sánchez-Criado, J.E. (1982) Involvement of the vomeronasal system in the reproductive physiology of the rat. In Olfaction and Endocrine Regulation, pp. 209-222. Ed. W. Breipohl. IRL Press, London.

Smithers, R.H.N. (1971) The Mammals of Botswana. Mus. mem. Natl Mus. Monum. Rhod. 4, 1-340.

Smithers, R.H.N. (1983) The Mammals of the Southern African Subregion. University of Pretoria, Pretoria.

Vandenbergh, J.G. (Ed.) (1983a) Pheromones and Reproduction in Mammals. Academic Press, New York.

Vandenbergh, J.G. (1983b) Pheromonal regulation of puberty. In Pheromones and Reproduction in Mammals, pp. 95-112. Ed. J. G. Vandenbergh. Academic Press, New York.

Van Der Lee, S. \& Boot, L.M. (1955) Spontaneous pseudopregnancy in mice. Acta physiol. pharmacol. neerl. 4, 442-444.

Van Der Lee, S. \& Boot, L.M. (1956) Spontaneous pseudopregnancy in mice. II. Acta physiol pharmacol. neerl. 55, 213-214.

Weir, B.J. \& Rowlands, I.W. (1973) Reproductive strategies of mammals. Annual Rev. Ecol. Syst. 44, $139-163$.

Westlin-Van Aarde, L.M. (1988) Reproduction in a laboratory colony of the pouched mouse, Saccostomus campestris. J. Reprod. Fert. 83, 773-778.

Received 3 October 1988 